\title{
Alpha Adrenergic Receptors: A Brief Perspective
}

\author{
Dr. SangavaiMathiazhagan ${ }^{1}$, Dr. S. Anand ${ }^{2}$, Dr. R. Parthiban ${ }^{3}$ \\ Post Graduates, Department of Pharmacology, SreeBalaji Medical College and Hospital, Chromepet, Chennai.
}

\begin{abstract}
In the last decade, knowledge of $\alpha$-adrenoceptors has expanded enormously. It is the purpose of this review to present the current status of our knowledge of alpha adrenergic receptor subtypes. The goal is to provide a brief perspective as a context for our current understanding and to highlight the gaps in our current understanding. From a pharmacological perspective, it should permit the development of very selective drugs with relatively few side effects.
\end{abstract}

Key Words: $\alpha$-adrenergic receptors, subtypes, locations, functions, agonists, antagonists.

\section{History}

Historically, adrenergic receptors were divided into two major types, $\alpha$ - and $\beta$-adrenergic receptors (1). Theadrenotropic receptors are those hypothetical structures or systems located in, on or near the muscle or gland cells affected by epinephrine (2). The concept of a receptive mechanism was introduced by Langley $(3,4)$ to explain the action of curare on skeletal muscle. Dale was probably the first to make significant use of the receptor concept in connection with the sympathetic nervous system. In his classical paper (5) on the sympatholytic action of the ergot alkaloids, he recognized that what he called the sympathetic myoneural junction could also be called 'the receptive mechanism for adrenaline'; and he used this mechanism to ex plain the fact that the ergot alkaloids prevented only the motor (excitatory) actions of epinephrine and had no effect on the inhibitory actions of epinephrine or on the excitatory actions of barium or pituitrin.

\section{Subtypes of Alpha Adrenergic Receptors(11)}

The initial evidence for subtypes of $\alpha 1$-adrenergic receptors was obtained in studies of adrenergic receptor mediated contraction of various vascular smooth muscles $(6,7)$. Data from radioligand binding studies, on the other hand, have produced a consistent definition of $\alpha$ adrenergic receptor subtypes, which has been confirmed by the molecular cloning of these receptors (8). $\alpha$-adrenergic receptor

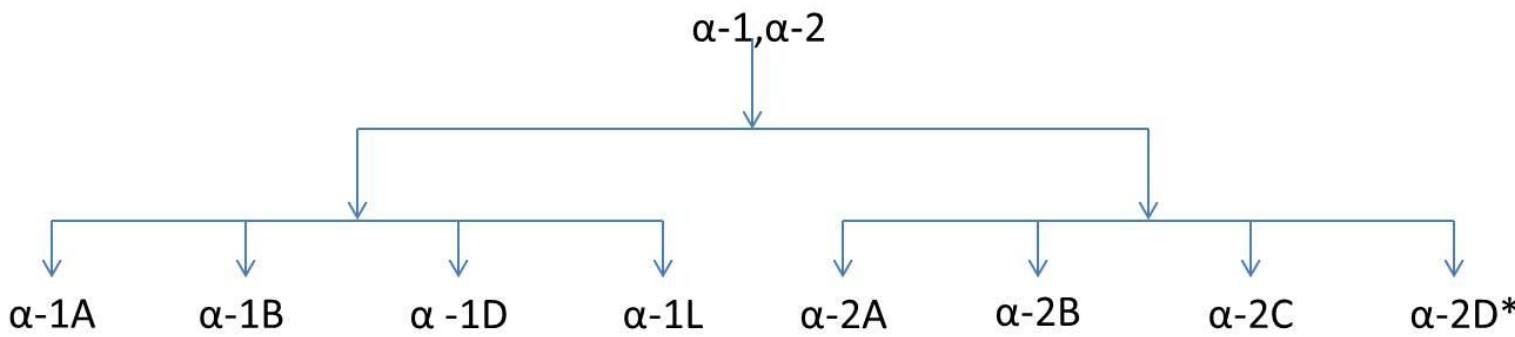

*In animal models $(9,10)$

\section{LOCATION OF ALPHA ADRENERGIC RECEPTORS (12)}

\begin{tabular}{|c|l|}
\hline $\begin{array}{l}\text { SUBTYPE ALPHA } \\
\text { ADRENOCEPTOR }\end{array}$ & \multicolumn{1}{|c|}{ LOCATION } \\
\hline$\alpha-1 \mathrm{~A}$ & $\begin{array}{l}\text { Vascular Beds ( vena cava, saphenous vein, pulmonary vein, } \\
\text { mammary, mesenteric, splenic, hepatic, omental, renal, pulmonary, } \\
\text { and epicardialcoronay vessels) }\end{array}$ \\
\hline$\alpha-1 \mathrm{~B}$ & Heart, CNS \\
\hline$\alpha-1 \mathrm{D}$ & Aorta \\
\hline$\alpha-1 \mathrm{~L}$ & Vascular smooth muscle (19,20) \\
\hline$\alpha-2 \mathrm{~A}$ & Presynaptic autoceptor in central neurons, CNS \\
\hline$\alpha-2 \mathrm{~B}$ & Blood vessels \\
\hline$\alpha-2 \mathrm{C}$ & Adrenal medulla and brain \\
\hline$\alpha-2 \mathrm{D}$ & Bovine pineal gland and rat submaxillary gland \\
\hline
\end{tabular}

In animal models $(9,10)$ 
MECHANISM OF ALPHA ADRENERGIC RECEPTORS (12)

$\alpha-2$ mediated mechanism:

- Inhibiting adenylyl cyclase(15)

- Attenuating cAMP response (16)

- Activating G-protein-gated potassium channels leading to membrane hyperpolarization(17)

- Inhibiting voltage gated calcium channels

- Activation of second messenger systems:

a) Acceleration of $\mathrm{Na}^{+} / \mathrm{H}^{+}$exchange

b) Stimulation of phospholipase $\mathrm{C}_{\beta 2}$ activity

c) Stimulation of arachidonic acid mobilization

d) increased phosphoinositide hydrolysis

e) Increased intracellular availability of Calcium is involved in the smooth muscle-contracting effect of $\alpha 2$ adrenergic receptor agonists.

f) Plays a major role in inhibiting Norepinephrine release from sympathetic nerve endings and sup- pressing sympathetic outflow from the brain

a-1 mediated mechanism:

- $\quad$ activation of the Gq-PLC ${ }_{\beta}-\mathrm{IP} 3-\mathrm{Ca}^{2+}$ pathway (13)

- $\quad$ activation of other $\mathrm{Ca}^{2+}$ and calmodulin- sensitive pathways (14)

- activation of PKC. PKC phosphorylates many substrates, including membrane proteins such as channels, pumps, and ion-exchange proteins.

- stimulation of phospholipase A2 leads to the release of free arachidonate, which is then metabolized via the cyclooxygenase and lipoxygenase pathways to the bioactive prostaglandins and leukotrienes, respectively.

- Phospholipase D hydrolyzes phosphatidylcholine to yield phosphatidic acid (PA).

- PA itself may act as a second messenger by releasing $\mathrm{Ca}^{2+}$ from intracellular stores, it also is metabolized to the second messenger DAG.

- Phospholipase D is an effector for ADP-ribosylating factor (ARF), suggesting that phospholipase D may play a role in membrane trafficking.

- $\quad \alpha-1$ receptors are capable of regulating a $\mathrm{Ca}^{2+}$ channel via a $\mathrm{G}$ protein.

FUNCTIONS OF ALPHA ADRENERGIC RECEPTORS

\begin{tabular}{|c|l|}
\hline $\begin{array}{l}\text { SUBTYPE ALPHA } \\
\text { ADRENOCEPTOR }\end{array}$ & \multicolumn{1}{|c|}{ FUNCTION } \\
\hline$\alpha-1 \mathrm{~A}$ & Vasoconstriction \\
\hline$\alpha-1 \mathrm{~B}$ & $\begin{array}{l}\text { Promotes cardiac growth, mediate behaviors such as reaction to } \\
\text { novelty and exploration and are involved in behavioral sensitizations } \\
\text { and in the vulnerability to addiction }\end{array}$ \\
\hline$\alpha-1 \mathrm{D}$ & Vasoconstriction \\
\hline$\alpha-1 \mathrm{~L}$ & Vasoconstriction (19,20) \\
\hline$\alpha-2 \mathrm{~A}$ & $\begin{array}{l}\text { Antinociceptive effects, sedation, hypothermia, hypotension, and } \\
\text { behavioural actions. }\end{array}$ \\
\hline$\alpha-2 \mathrm{~B}$ & Vasoconstriction \\
\hline$\alpha-2 \mathrm{C}$ & $\begin{array}{l}\text { inhibiting the release of catecholamines from the adrenal medulla and } \\
\text { modulating DA neurotransmission in the brain. }\end{array}$ \\
\hline$\alpha-2 \mathrm{D}^{*}$ & Probable visual function in bovine neurosensory retina \\
\hline
\end{tabular}

*In animal models $(9,10)$

\section{BRIEF REVIEW OF DRUGS AFFECTING $\alpha$-ADRENERGIC RECEPTORS (18) AGONISTS OF ALPHA ADRENERGIC RECEPTORS}

- NON-SELECTIVE ENDOGENOUS CATECHOLAMINES
1) Adrenaline
2) Noradrenaline
3) Dopamine

- NON-SELECTIVE SYNTHETIC CATECHOLAMINES
1) Dipivefrine
2) Dobutamine
3) Fenoldopam
4) Etilefrine 
5) Talipexole (B-HT920)

6) Octopamine

7) Amitraz

8) Indanidine

- $\quad$ SELECTIVE $\alpha-1$ AGONISTS (NON-CATECHOLAMINES)
1) Phenylephrine
2) Methoxamine
3) Naphazoline
4) Oxymetazoline
5) Xylometazoline
6) Midodrine
7) Mivazerol
8) Cirazoline

- $\quad$ SELECTIVE $\alpha-2$ AGONISTS (NON-CATECHOLAMINES)

1) Clonidine

2) Apraclonidine

3) Brimonidine

4) Alpha methyldopa

5) Guanfacine

6) Guanbenz

ANTAGONISTS OF ALPHA ADRENERGIC RECEPTORS

- NON-SELECTIVE IRREVERSIBLE BLOCKERS

1) Phenoxybenzamine

- NON-SELECTIVE REVERSIBLE BLOCKERS

1) Phentolamine

2) Tolazoline

3) Anisodamine,

- SELECTIVE REVERSIBLE $\alpha-1$ BLOCKERS

1) Prazosin

2) Terazosin

3) Doxazosin

4) Alfuzosin

5) Bunazosin

6) Tamsulosin ( $\alpha$-1A subtype selective)

7) Silodosin

8) Indoramin

9) Urapidil

- SELECTIVE $\alpha-2$ BLOCKERS

1) Yohimbine

2) Idazoxan

3) Cirazoline

\section{Conclusion}

A major message of this review is that $\alpha 1, \alpha 2$,are the two major subtypes of $\alpha$-adrenergic receptors, and that $\alpha 1$ - and $\alpha 2$-adrenergic receptors are not more closely related to each other. The identification of multiple receptor subtypes for the major types of adrenergic receptors has obvious implications for drug therapy. It is to be expected that more and better selective drugs for the various subtypes will be developed in the near future. These will be important research tools as well as potentially new therapeutic agents. A major impediment at the current time to the development of better therapeutic agents is a paucity of knowledge as to which functions are mediated by which receptor subtypes. This is an area that clearly needs immediate attention. Current studies under way on the localization of the various subtypes in various tissues and regions of tissues may help to correlate receptor subtype with function. It appears that receptor subtype- specific antibodies may be developed in the near future and these will also be an important tool. Another important area in the next few 
years will be a study of subtype- specific regulation of the protein and mRNA level. Further in the future it seems reasonable to expect that it may be possible to regulate levels of receptors and $G$ proteins in order to produce therapeutic effects, rather than regulating the degree of receptor occupancy by the agonist as is currently done.

\section{References}

[1]. 'From a Nervous System Function and Disorders Thematic Symposium entitled Subtypes of a1 and ct Adrenergic Recep- tors presented at the 74th Annual Meeting of the Federation of American Societies for Experimental Biology, Washington, D. C., April 4, 1990.

[2]. A STUDY OF THE ADRENOTROPIC RECEPTORS RAYMOND P. AHLQUIST, From the Department of Pharmacology, Uniwvsity of Georgia School of Medicine AUGUSTA, GEORGIA, June 1948,volume 153, pages 586-600

[3]. LANGLEY, J. N. J. Physiol. 33: 374, 1905.

[4]. LANGLEY, J. N. Proc. Roy. Sot. 78B : 170, 1906

[5]. DALE, H. H. J. Plzysiol. 34: 163, 1906.

[6]. McGrath, J. C., Brown, C. M., and Wilson, V. G. (1989) Alpha-adrenoceptors: a critical review. Med. Res. Rev. 9, 407-533

[7]. Minneman, K. P. (1988) ai-Adrenergic recetor subtypes, inositol phosphates, and sources of cell Ca .Pharmacol. Rev. 40, 87-119

[8]. Harrison, J. K., Pearson, W. R., and Lynch, K. R. (1991) Molecular characterization of ai- and ct2-adrenoceptors. TIPS 12, 62-67

[9]. Simonneauz, V., Ebadi, M., and Bylund, D. B. (1991) Iden- tification and characterization of alpha-2D adrenergic receptors in bovine pineal gland. Mol. Pharmacol. 40, 235- 241

[10]. Michel, A. D., Loury, D. N., and Whiting, R. L. (1989) Dif- ferences between the a2-adrenoceptor in rat submaxillary gland and the Uta- and a25-adrenoceptor subtypes. Br. j Phannacol. 98, 890-897

[11]. Subtypes of a1- and a2-adrenergic receptors -DAVID B. BYLUND Department of Pharmacology, College of Medicine, University of Nebraska Medical Center, Orn a, Neb 5. 68198.6260, USA, Vol. 6 February 1992 The FASEB Journal, pages 832-839.

[12]. Goodman and Gilman's Manual of Pharmacology and Therapeutics, 2008,McGraw Hill Companies, Inc.,page 111.

[13]. Han, C., Wilson, K. M., and Minneman, K. P. (1990) a1- Adrenergic receptor subtypes and formation of inositol phosphates in dispersed hepatocytes and renal cells. Mol. Phannacol. 37, 903-910

[14]. Wilson, K. M., and Minneman, K. P. (1990) Different path- ways of [3H]inositol phosphate formation medicated by Ula- and albadrenergic receptors. J. Biol. C/tern. 265, 17601-17606

[15]. Bylund, D. B., and Ray-Prenger, C. (1989) Alpha-2A and alpha-2B adrenergic receptor subtypes: attenuation of cyclic AMP production in cell lines containing only one receptor subtype. J. Pharmacol. Exp. Titer. 251, 640-644

[16]. Murphy, T. J., and Bylund, D. B. (1988) Characterization of alpha-2 adrenergic receptors in the OK cell, an opos- sum kidney cell line. jPharmacol. Exp. TIter. 244, 571-578

[17]. Isom, L. L., and Limbird, L. E. (1988) What happens next? A hypothesis linking the biochemical and elec-trophysiologicalsequelae of alpha-2 adrenergic receptor occupancy with the diverse receptor-mediated physiologi- cal effects. In The Alpha-2 Adrenergic Receptors (Limbird, L., ed) Humana, 323-363

[18]. Principles of Pharmacology by HL Sharma \& KL Sharma, second edition, paras publications, drugs affecting sympathetic nervous system,pages $155-190$

[19]. Flavahan NA, Vanhoutte PM. $\alpha_{1}$-Adrenoceptor subclassification in vascular smooth muscle. Trends Pharmacol Sci. 1986;7:347349 .

[20]. Muramatsu L, Ohmura T, Hashimoto S, Oshita M. Functional subclassification of vascular $\alpha_{1}$-adrenoceptors. Pharmacol Commun. 1995;6:23-28. 